\title{
Precision Medicine for Paediatric Severe Asthma: Current Status and Future Direction [Corrigendum]
}

Ramphul M, Lo DKH, Gaillard EA. J Asthma Allergy. 2021;14:525-538.

The authors have advised that Figures 1 and 2 on pages 528 and 533, respectively are in the reverse order. In the original article, Figure 1 appears as Figure 2, and Figure 2 as Figure 1. The Figures with the correct captions are as follows.

The authors apologize for this error. 

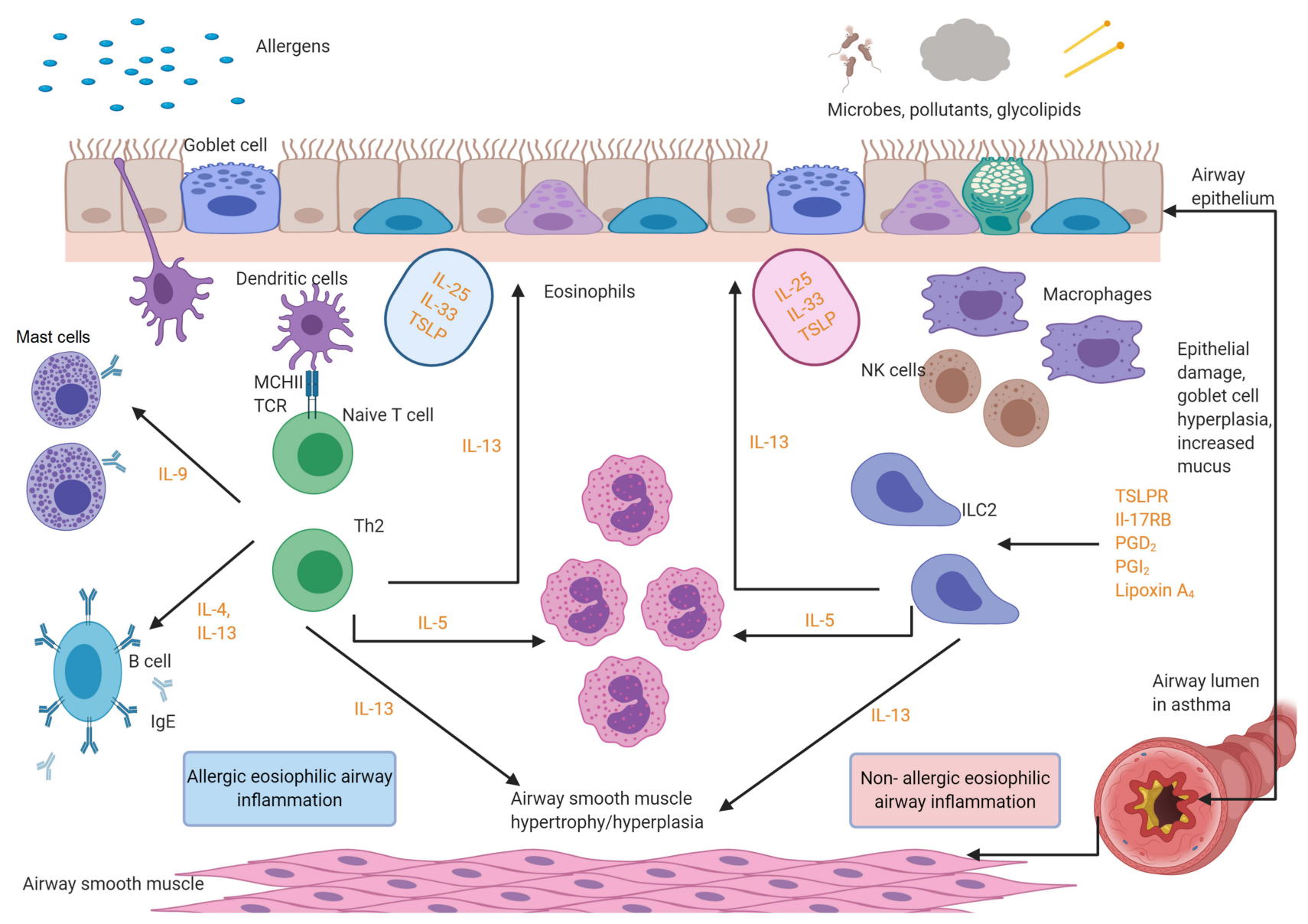

Figure I Eosinophilic asthma inflammatory pathways. There are two aetiologies for eosinophilic inflammation in asthma: an allergic pathway triggered by allergens and a non-allergic mechanism triggered by microbes, pollutants and glycolipids. The key mediators in the pathways are depicted below. Eosinophils release cationic proteins, ${ }^{57}$ which lead to bronchial epithelial tissue damage, thus causing airways hyper-responsiveness. Eosinophils also lead to airway smooth muscle cell proliferation through increased eosinophils adhesion caused by the release of cationic proteins and the eosinophilic effect on transforming growth factor- $\beta$ I and gene coding of wingless/integraseI signaling. IL-I3 triggers mucus hyper-secretion. Figure created with BioRender.com.

Abbreviations: IgE, immunoglobulins E; IL, interleukins; ILC2, type 2 innate lymphoid cells; TCR, T-cell receptors; NK, natural killer T cell; TSLPR, thymic stromal lymphopoietin receptor; PG, prostaglandin; ECP, eosinophil cationic protein; EPX, eosinophil protein X; EPO, eosinophil peroxidase; MBP, major basic protein. 

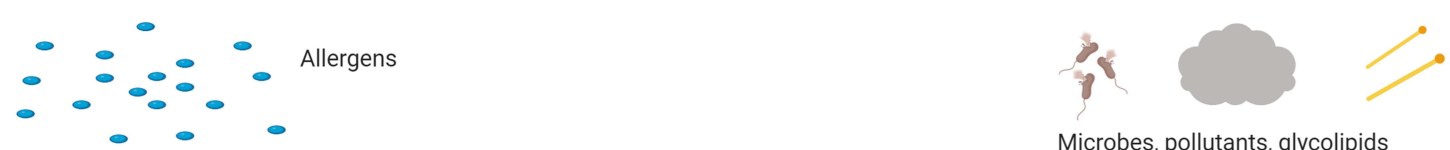

Microbes, pollutants, glycolipids

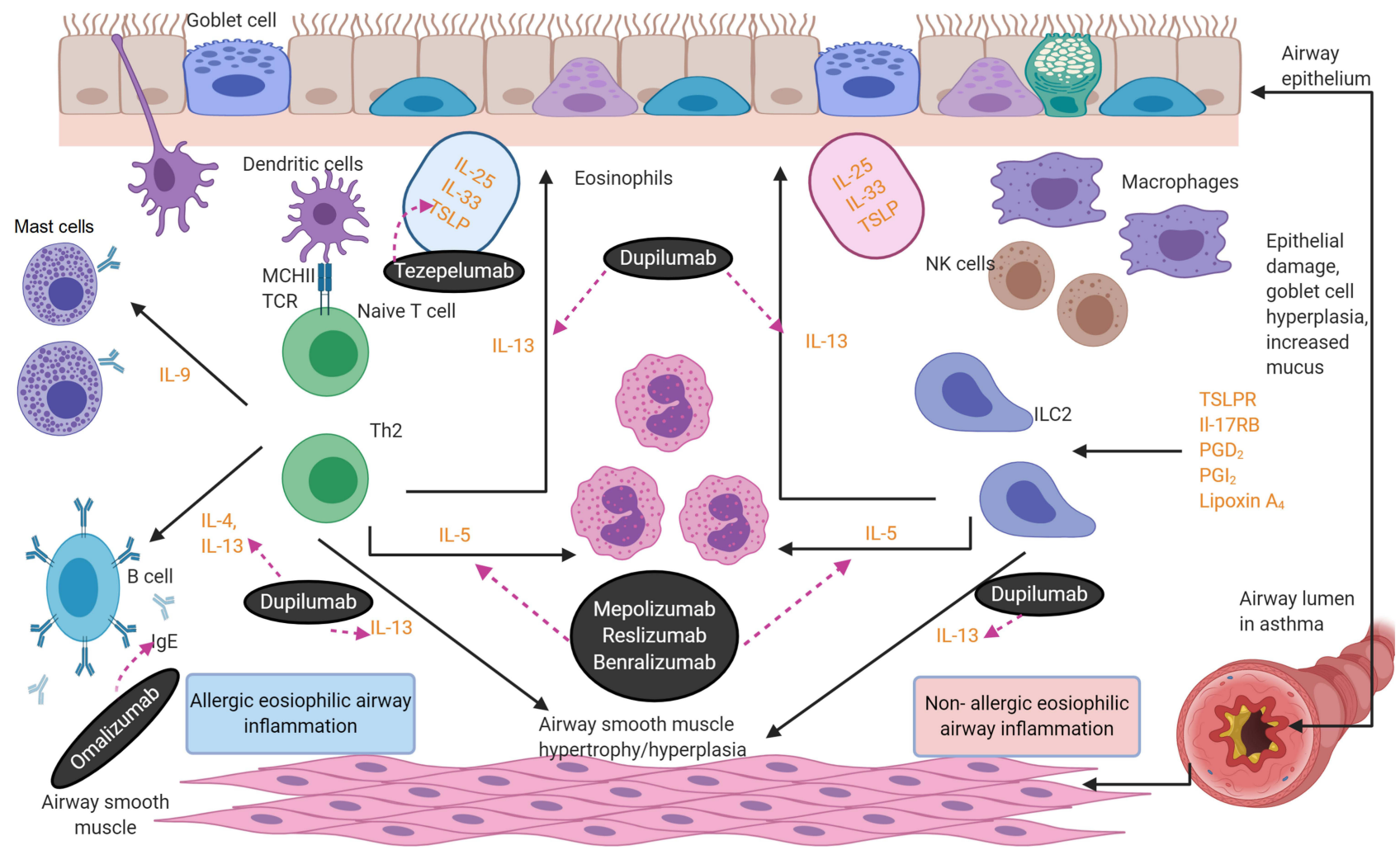

Figure 2 Licensed mediator cascade of biologics used in eosinophilic asthma. The figure shows the targets for the licensed biologics. Omalizumab is an IgE-blocker. Mepolizumab, reslizumab and benralizumab are anti IL-5 agents. Dupilumab is an Anti-IL-4/anti-IL-13 agent. Figure created with BioRender.com.

Abbreviations: IgE, Immunoglobulins E; IL, interleukins; ILC2, type 2 innate lymphoid cells; TCR, T-cell receptors; NK, natural killer T cell; TSLPR, thymic stromal lymphopoietin receptor; PG, prostaglandin.

\section{Publish your work in this journal}

The Journal of Asthma and Allergy is an international, peer-reviewed open-access journal publishing original research, reports, editorials and commentaries on the following topics: Asthma; Pulmonary physiology; Asthma related clinical health; Clinical immunology and the immunological basis of disease; Pharmacological interventions and new therapies. The manuscript management system is completely online and includes a very quick and fair peer-review system, which is all easy to use. Visit http://www.dovepress.com/testimonials.php to read real quotes from published authors. 